

Bayero Journal of Pure and Applied Sciences, 4(1): 56 - 58

Received: January, 2011

Accepted: April, 2011

ISSN 2006 - 6996

\title{
ANALYSIS OF SOME MINERAL ELEMENTS IN SELECTED SORGHUM CULTIVARS
}

\author{
W. L. O. Jimoh ${ }^{1}$ and M. S. Abdullahi ${ }^{2}$ \\ ${ }^{1}$ Department of Pure and Industrial Chemistry, BUK \\ ${ }^{2}$ National Biotechnology Development Agency, Abuja
}

\begin{abstract}
Ten sorghum samples were used for this study. Six samples(local) from Kibiya, Tsakuwa, BurumBurum in Kano State, two samples from each of the sampling areas and four improved samples from Institute of Agricultural Reasearch, Zaria.The varieties are White Kibiya (WK), Yellow Kibiya (YK), White Tsakuwa (WT), Yellow Tsakuwa (YT), White Burum-Burum (WB) and Yellow Buru-Burum (YB) were the local samples. Samsorg 14 (S14), Samsorg 17 (S17), Samsorg 40 (S40) and Samsorg 41 (S41) were the improved samples. The mineral composition of the sample studied shows highest distrbution pattern of $\mathrm{Fe}\left(\mathrm{YK}, 31.95 \mu \mathrm{gg}{ }^{-1}\right), \mathrm{Cu}\left(\mathrm{YT}, 7.27 \mu g \mathrm{~g}^{-1}\right), \mathrm{Zn}\left(\mathrm{S}_{40} 59.81 \mathrm{\mu gg}^{-1}\right), \mathrm{Mg}$ $\left(Y K .110 .74 \mu g g^{-1}\right) \mathrm{Ca}\left(Y T, 40.85 \mu g g^{-1}\right), C u\left(S_{17}, 8.0 \mu g g^{-1}\right), C d\left(S_{14}, 0.99 \mu g g^{-1}\right)$, and Pb was only detected in white Burum -Burum variety $\left(0, .64 \mu g g^{-1}\right)$.
\end{abstract}

Keywords: Minerals, Sorghum, Cultivars, Nutrients

\section{INTRODUCTION}

All plants and animals depend ultimately upon their environment for the supply of mineral nutrients circled through atmospheric and aqueous pollution which make direct or indirect impact on humans with the supply of unsafe and toxic minerals(Caberera et al.,1994). Human health may thus be directly affected by ingesting foods. The effect becomes pronounced due to imbalance of macro- and micro-nutrients. The assessment of these nutrients in various raw foods depends on source, material and locality (Takas and Tatar, 1997)

Safe limits of toxic elements are applied in most instances because of first, possible toxicity of the element and second, the feasibility of the limit in relation to good manufacturing practice. An element is essential when it is consistently determined to be present in all healthy living tissues and when its deficiency symptoms are noted, with depletion or removal, which disappears when the elements are provided to the tissues (Olivares and Uauy, 1996) .Of the essential metals, iron, copper and zinc are well known for their biochemical role in the human body. Iron is an essential metal in the biochemical system, i.e. hemoglobin in blood, which is the most important iron complex consisting of the globin protein with four heme units attached to it. Likewise, copper is found in enzymes capable of carrying oxygen as hemoglobin does, and it is actually required in the formation of this substance. Zinc, another essential element is approximately100 times as abundant as copper in the human body. It has the ability to occupy low symmetry sites in enzymes(Corn, 1993).

As far as non-essential elements are concerned, chromium is known to cause lung cancer (Mueller and Anke, 1994).. Lead accumulation results first in reduced functioning of kidney, liver and brain cells and later in complete breakdown of the tissues. Cadmium and its compounds are also toxic to humans. They produce acute and chronic symptoms varying in intensity from irritation to extensive metabolic disturbance (Mueller and Anke, 1994)

Human body requires both metllic and nonmetallic elements for healthy growth and development within certain permissible limits (The optimum concentration needed for this purpose varies widely from one element to another, from infant to childhood to adult and from male to female). The determination of these elements in beverages, water, food, plant and soil is thus of outmost importance and is currently the subject of studies by various reasearchers (Saud and AL-Oud,2003; WHO,1998a,b).

The objective of this work was to determine the mineral composition of different sorghum cultivars.

\section{MATERIALS AND METHODS}

Collection of Samples: Six different sorghum samples used in this study were collected from Kibiya, Tsakuwa and Burum-Burum in Kano State.Two samples each were obtained from each of the sampling areas (WK, YK, WT, YT, WB and YB) and four hybrid samples (S14, S17,S40 and S41) from Institute of Agricultural Research, Zaria. The samples were sorted, cleaned and ground separately using pestle and mortar to a powder form. They were stored in plastic containers for analysis.

\section{Analytical Procedure}

Each of the oven dried samples $(10 \mathrm{~g})$ was weighed in the crucible. The crucible and its contents were placed in muffle furnace and the temperature was set to $550^{\circ} \mathrm{C}$ until constant weight was obtained. Fifty cubic centimeters $\left(50 \mathrm{~cm}^{3}\right)$ of $0.1 \mathrm{M} \mathrm{HNO}_{3}$ (Analar grade) was added to dissolve the ash.

Determination of Minerals:Working standard solutions of $\mathrm{Fe}, \mathrm{Cu}, \mathrm{Mg}, \mathrm{Ca}, \mathrm{Zn}, \mathrm{Pb}$, and $\mathrm{Cd}$ prepared from stock standard solution $\left(100 \mathrm{mgdm}^{-3}\right)$ and absorbance were obtained for various working standards for each element in the samples using atomic absorption spectrophotometer (AAS) Unicam 969. 
The absorbance was plotted against concentration and the linear calibration curves formed revealed the actual concentration of each sample. A blank reading was also taken and necessary correction was made during the calculation of concentration of various elements.

\section{RESULTS AND DISCUSSION}

Table1 shows the mineral contents of the samples analyzed.

Iron content in most of the samples is less than the values observed for calcium. This is because iron is probably converted into less easily absorbed ferric $\left(\mathrm{Fe}^{3+}\right)$ ion at high $\mathrm{pH}$ value (Nijjar, 1990). The concentration of iron $\left(\mu \mathrm{gg}^{-1}\right)$ in local sample follows the order; $\mathrm{YK}>\mathrm{YT}>\mathrm{YB}>\mathrm{WK}>\mathrm{WB}$ and that of the improved samples is S14 > S40 > S17 > S41 Yellow sorghum from Kibiya had the highest iron value of $31.95 \mu \mathrm{gg}^{-1}$ and the least value was $9.28 \mu \mathrm{gg}^{-1}$ obtained from S14.Chavan et al.(2009) reported iron content of 4.13-5.98ugg ${ }^{-1}$ with a mean of $5.15 \mathrm{ugg}^{-1}$ in sorghum. Zinc is involved in many enzymes in plant metabolism. Zinc is taken up by plant predominantly in the form of divalent $\mathrm{Zn}^{2+}$ (Nijjar, 1990). Zinc is an essential component of proteinases and peptidases enzymes (Prince et al, 1972). The result of zinc content of the local sample revealed a mean value of $31.34 \mu^{-1}$ and had a ranged of $27.66-38.89-1 \mu g^{-1}$. The improved sample had a mean value of $36.21 \mu^{-1}$ with a range of $6.86-59.81 \mu^{-1}$.Abu et al.,(2000) reported that zinc content of $0.39 \mathrm{ugg}^{-1}-25.61 \mathrm{ugg}^{-1}$ while Chavan et al (2009) reported zinc content of 1.33 - 1.93 ugg $^{-1}$ in sorghum and both values are lower than the result of this study.

The result of this study revealed that in all the samples (local and improved) analyzed, Cu was detected, and this confirmed that $\mathrm{Cu}$ is required for plant life. It was shown that $\mathrm{Cu}$ was essential for the normal growth of plant (Nijjar, 1990). The level of copper was shown in Table 1, the concentration of the local sample has mean value of $3.35{\mu g g^{-1}}^{-1}$ and range $0.94-4.18 \mu^{-1}$ while the improved sample had a higher mean value of $5.64 \mu^{-1}$ and range of $0.58-$ $8.01 \mathrm{\mu gg}^{-1}$.Chavan et al.,(2009) reported a lower value of $0.53-1.08 \mathrm{ugg}^{-1}$ and a mean value of $0.86 \mathrm{ugg}^{-1}$. The copper content of grain is related to some extent to the soil copper level, but other factors such as drainage condition and herbage species affect the copper content (Nijjar, 1990). Generally about $0.1 \%$ of the total $\mathrm{Mg}$ in plants and about $10 \%$ of the leaf $\mathrm{Mg}$ is constituent of chlorophyll (Nason and Mc Elory, 1963). The magnesium concentration in the local sample has a mean value of $75.96 \mu \mathrm{gg}^{-1}$ and range of

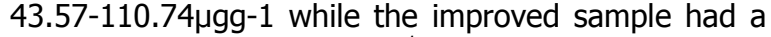
mean value of $48.81 \mathrm{\mu gg}^{-1}$ and range of 44.14$65.44 \mu g^{-1}$. These values relate closely with those reported by Chavan et al.,(2009) of $168-218$ ugg $^{-1}$ with a mean of $195 \mathrm{ugg}^{-1}$ and Abu et al.,(2000) value of $1.68-106.15$ ugg $^{-1}$.

Calcium is essential for the growth of meristems, roothairs and root tips.It affects the permeability of cell membrane and influences the transport of carbohydrate and protein in the plant. Calcium deficency in plants leads to stunted growth with particularly poor root development (stanley, 1995). Calcium in the local sample has a mean value of $27.75 \mu \mathrm{gg}^{-1}$ with a range of $16.92-40.85 \mu \mathrm{gg}^{-1}$ and the improved sample had range value of 9.98 $24.51 \mu \mathrm{gg}^{-1}$ with a mean value of $19.12 \mu \mathrm{gg}^{-1}$. Abu et al., (2000) reported a value of 9.13 - 42.92ugg ${ }^{-1}$ Chavan et al.,(2009) $24-40 \mathrm{ugg}^{-1}$ and both values are in accord with the results obtained in this study. Lead was not detected in all the samples except WB (0.64 $\mu \mathrm{gg}-1)$ which is still below safe daily intake of $15-100 \mu^{-1} \quad$ (WHO, 1985). The reason for accumulation is that $\mathrm{Pb}$ is relatively easily taken up by food crops and may also be due to foliar absorption of atmospheric deposits on plant leaves (Kumar, et al.,(2009). The toxic element cadmium shows a low concentration in only three samples viz S14 $(0.99 \mu g g-$ 1) S41 $\left(0.14 \mu \mathrm{gg}^{-1}\right)$ and WB $\left(0.16 \mu \mathrm{gg}^{-1}\right)$, and is in agreement with the result obtained by Kumar et al.,(2009) of $0.99 u^{-1} g^{-1}$. Much of the cadmium that is absorbed by the plant is retained in the root. For example 20 out of 23 species grown in solution culture, more than half of the cadmium taken up was retained in the root (Alan, 1996).

Table 1:Mineral and Trace elements Concentration s of the Samples Analysed $\left(\mu_{g g}{ }^{-1}\right)$

\begin{tabular}{|c|c|c|c|c|c|c|c|}
\hline $\begin{array}{l}\text { ELEMENT } \\
\text { SAMPLE }\end{array}$ & $\mathrm{Fe}$ & Cd & $\mathrm{Cu}$ & Zn & $\mathbf{P b}$ & Mg & $\mathrm{Ca}$ \\
\hline YB & 19.25 & $\overline{N D}$ & 2.19 & 36.89 & $\overline{N D}$ & 66.44 & 25.23 \\
\hline WT & 15.09 & 0.37 & 0.94 & ND & ND & 65.02 & 16.92 \\
\hline $\mathrm{YT}$ & 26.09 & ND & 7.27 & ND & ND & 104.82 & 40.85 \\
\hline WK & 15.74 & ND & 3.59 & 29.5 & ND & 65.18 & 25.39 \\
\hline YK & 31.95 & ND & 4.18 & ND & ND & 110.74 & 40.53 \\
\hline WB & 13.03 & 0.16 & 1.9 & 27.62 & 0.64 & 43.57 & 17.58 \\
\hline MEAN & 20.19 & & 3.35 & 31.34 & & 75.96 & 27.75 \\
\hline S14 & 21.45 & 0.99 & 6.91 & 59.76 & ND & 64.95 & 24.51 \\
\hline S41 & 9.28 & 0.14 & 0.58 & 6.86 & ND & 20.94 & 9.98 \\
\hline S40 & 19.25 & ND & 7.06 & 59.81 & ND & 65.44 & 24.15 \\
\hline S17 & 18.51 & ND & 8.01 & 18.39 & ND & 44.14 & 17.82 \\
\hline MEAN & 18.12 & & 5.64 & 36.21 & & 48.87 & 19.12 \\
\hline
\end{tabular}

Key : YB $=$ Yellow B/burum, WT $=$ White Tsakuwa, YT = Yellow Tsakuwa, WK = White Kibiya, YK = Yellow Kibiya, WB $=$ White $\mathrm{B} /$ burum 


\section{Conclusion}

The result of this study shows that sorghum contains essential mineral in appreciable quantities to meet the requirement of the Recommended Dietary Allowances. Lead and Cadmium levels obtained in this work are far below safe daily intake of World Health

\section{REFERENCES}

Abu, A.E., Aba, D.A., Chindo, P.S., Ango, K.M. and Maigida, D.N. (2000). Evaluation of sorghum grain for traditional and industrial uses. Institute of agricultural research, Zaria.

Alan, W.(1996). Soil and Environment, University of Reading, London. Pp $1-12,107-130$.

Caberera, C., Gallego, C., Lopez, M.C., Lorenz, M. L.and Lillo, M.E. (1994).Determination of Levels of Lead Contaminations in Food and Feed Crops, J. AOAC Int. 77: 1249-52

Chavan, U. D, Patil, J. V. and Shinde, M. S. (2009). Nutritional and Roti quality of Sorghum Genotypes, Indonesian Journal of Agricultural Science 10 (2): 80-87

Corn, M.(1993). Handbook of Harzadous Materials, Academic Press, San Diego, CA Pp 772.

http://www.cababstractsplus.org/abstract

http://www.en.wikipedia.org/wiki/Dietary-ReferenceIntake. Retrieved December 12, 2009.

Ingaski, M.A (2005) Proximate Analysis of Cassia siamea, Msc dissertation (unpublished) Department of Chemistry, Usman Danfodio University, Sokoto.

Kumar A.,Sharma,I.K.,Sharma, A.,Varshney, S. and Verma,P.S.(2009). Heavy Metal Contamination of Vegetable Foodstuffs in Jaipur (India).Electronic Journal of Environmental,Agricultural, and Food Chemistry 8(2): 96-101.

Mueller, M. and Anke, M. (1994). Distribution of Cadmium in the Food Chain (soil-planthuman), of a Cadmium Expose Area and the
Organisation in all the samples at levels that pose no any threat to human health. The result, of this work has also shown that the values of minerals in the improved varieties from the Institute for Agricultural research (IAR) Zaria are higher as compared to the local samples.

Health Risks of the General Population. Sci. Total Environ. 156:151-8.

Nason, A. and Mc., Elory, W.D. (1963). Modes of Action of Essential Mineral Elements.In: F.C. Steward ed., Plant Physiology, Vol. III. Academic Press. NewYork. pp 451-536.

Nijjar, G. S.,(1990). Nutrition of Fruit, Punjab Agric. Uni. Ludhana. Pp10-304.

Olivares, M. And Uauy, R.(1996). Limits of Metabolic Tolerance to Copper Biological Basis for Present Recommendation and Regulation. Am. J. Clin. Nutr. 63: 846s-52s

Prince, C.A., Clark, H. E. And Funkhouse, E.A.(1972).Functions of Micronutrients in Plants: Micronutrients in Agriculture, Soil Sience Soc. America Madison, Wisconsin..

Saud, S. and AL-Oud, (2003). Heavy metal contents in tea and herb leaves. Pakistan Journal of Biological Sciences, 6:208-212.

Stanley, A. B. (1995). Soil Nutrient Bioavailability Purdue University, New York.Pp. 180-372.

Takas, S. and Tatar, A.(1997).Trace Elements in the Environment and in Human Organs. Environ. Res. 42, 312-20.

WHO (1985). Technical Report series No. 724, PR 220 (WHO, Geneva).

WHO (1998a).Guidelines for Drinking Water Quality. $2^{\text {nd }}$ edition. Health and Other Supporting Information.World Health Organisation, Geneva,Pp 47-61.

WHO (1998b).Guidelines for Drinking Water Quality. $2^{\text {nd }}$ edition. Health and Other Supporting Information.World Health Organisation, Geneva,Pp 308-313. 